\title{
Vendida e comprada de Alberto Moravia
}

Venduta e comprata

Sérgio Gabriel Muknicka

(Unesp) 
Sou uma mulher jovem e bela, mulher de um homem jovem e rico. Uma vez por semana, entro no meu carro, saio da zona urbana, dirijo-me a uma certa rua no campo. Estaciono o carro em uma valeta e em seguida caminho talvez cem metros. Eis uma clareira em frente a um rústico portãozinho fechado com uma corrente e um cadeado enferrujados. Do outro lado da cerca de ripas, entrevê-se uma propriedade em estado de abandono: mato e arbustos por toda parte, árvores frutíferas com os frutos esparsos por terra a apodrecer, grandes árvores frondosas, jamais podadas, com os ramos e a folhagem secas misturadas aos ramos e à folhagem verdes. Sento-me na cerca de ripas, uma perna balançando no vazio e a outra com o pé apoiado muito em cima, sobre uma barra. Visto invariavelmente uma minissaia sem meia-calça e, sobretudo, sem calcinha. Estou, em suma, nua por baixo e calculei que, nesta posição, qualquer motorista que desemboque da curva, não muito longe, de frente para mim, consiga olhar imediatamente as minhas pernas até à escuridão da virilha. Nunca espero muito, até porque para dar a entender quem sou, ou melhor, quem finjo ser, finjo fumar um cigarro. E, de fato, nunca se passam mais do que dez minutos até que um automóvel pare e um rosto afogueado estenda-se para fora da janela. Ele me pergunta quanto quero; digo-lhe; quase todos aceitam; o carro, sob meu conselho, é estacionado ao lado da estrada; em seguida pego pela mão o cliente e guio-o ao longo da sebe de sabugueiro até certa trilha que eu mesma abri na sebe. A beira é íngreme, ajudo o homem a subir, depois vou a sua frente por um caminho em que a grama densa (estamos em maio, quando a grama está mais viçosa) conserva o rastro de minhas passagens anteriores. Vamos diretamente a uma grande árvore, e eu me deito imediatamente no chão. Ele dá de se deitar sobre mim, mas eu o empurro e digo-lhe que quero o dinheiro adiantado: "Desculpe, uns dias atrás tive uma péssima aventura, um escapou sem me pagar, tenho certeza de que você não faria isso, mas no fim que diferença faz, me pague agora e depois não pense mais nisso." Os homens, quando têm desejo, são bons e dóceis. Não há nenhum que não tire a carteira e não me dê a soma combinada. Depois ele se joga sobre mim e então, bem naquele momento, finjo me sentir mal. Solto um grito, revirome pela grama, comprimo o coração com uma mão. $\mathrm{O}$ homem aterrorizado afasta-se para trás, olha para mim. Embora gemendo e comprimindo com uma mão o coração, pego com a outra o dinheiro na bolsinha ainda aberta e devolvo-lhe balbuciando: "Sou doente do coração. Mas vá embora. É uma coisa que me acontece de vez em quando e depois passa. Naturalmente nem pensar em fazer amor. Aqui o seu dinheiro, desculpe, mas me deixe, vá." Imaginem o homem que, por um momento, temeu encontrar-se com uma moribunda nos braços. Não há nenhum deles que não pegue o dinheiro e não vá embora às pressas. Então, assim que estou certa de que ele foi mesmo embora, levanto-me, alcanço a estrada, ando até meu carro, entro nele, volto para casa, em Roma. Como eu disse, celebro esta espécie de rito uma vez por semana. Nunca me aconteceu 
de encontrar um cliente pela segunda vez. Se um deles me encontra, a recordação do meu súbito mal-estar tira-lhes qualquer desejo de aproximarem-se de mim de novo. $\mathrm{E}$ de resto, mesmo que me encontrasse com alguém suficientemente apaixonado para tentar de novo, estou bem decidida a repetir de novo a farsa do mal-estar repentino.

Essa espécie de ritual de certo modo simbólico por meio do qual consigo venderme sem dar-me tem uma origem precisa, naturalmente, e eu sei muitíssimo bem qual é. É necessário saber que quando me casei cinco anos atrás com Siro, meu marido, iludiame que ele me amava como eu o amava: apaixonadamente, exclusivamente. Mas essa ilusão durou pouco, não mais do que dura uma aventura qualquer. Depois de apenas dois meses do nosso casamento, descobri que ele me enganava, além de tudo, de uma maneira muito humilhante para mim, isto é, sem nenhum motivo sentimental particular ou, até mesmo, erótico, assim, como se fazem tantas coisas que sempre foram feitas, por costume, por automatismo. Siro costumava fazer amor com muitas mulheres e não parecia considerar o vínculo conjugal um motivo suficiente para renunciar a esse seu hábito.

Naturalmente eu comecei a sofrer porque, como disse, amava meu marido de um amor verdadeiro, apaixonado e exclusivo. Eu sabia que era traída e muitas vezes pensei, por minha vez, em me vingar traindo-o. Mas ao que parece sou incapaz de ser infiel. Naturalmente eu poderia tê-lo deixado. Mas, infelizmente, apesar da traição, continuava amando Siro.

O meu sofrimento tinha um ritmo seu, um método seu, ou melhor, conquistouos com o tempo. Eu sofria, sobretudo, nas primeiras horas da tarde. De fato, era esta a parte do dia em que eu não tinha nada para fazer; nada a não ser pensar em meu marido e em sua infidelidade.

Não tinha vontade de ver ninguém, não queria me distrair nem me ocupar, não sabia, ao fim das contas, o que fazer comigo mesma. Então, de repente, depois de ter tentado, em vão, ler um livro do qual me desfazia quase na mesma hora ou de ouvir um disco que eu parava depois dos primeiros giros ou de ver televisão a qual eu desligava após as primeiras imagens, vestia com pressa e fúria um casaco e saía. Entrava no carro e ia ao centro da cidade. O que me atraía lá, na confusão da multidão e do tráfego? Primeiro pensei que fosse, sem mais, a vida, da qual me sentia excluída; depois me dei conta de que a minha atração tinha, no fundo, um objeto bastante preciso. Eram as lojas que me atraíam, suas vitrines cheias de objetos postos à mostra para serem vendidos, sobretudo, as lojas de roupas.

Estacionava o carro e, em seguida, loja após loja, percorria lentamente as ruas do centro. Nesse ponto, devo notar que no passado nunca sentira pelas lojas nada além de enfado e repugnância. Sou uma daquelas mulheres, raras na minha casta, que se vestem com simplicidade, do jeito que vier está bom, a fim de não perder tempo e de 
não se encontrar na enfadonha necessidade de fazer uma escolha. Além disso, nunca consegui dar o salto do necessário ao supérfluo, do funcional ao elegante, do decoroso ao luxuoso. Mais do que me vestir, era-me suficiente cobrir-me. Por fim, me afeiçoava às roupas velhas, talvez porque me entediasse a compra de novas. Agora, no entanto, de repente, saída sabe-se lá de onde, descobria em mim uma vocação de consumidora inveterada. Essa vocação foi-me revelada pelo meu próprio aspecto físico. Aconteceume um dia de olhar-me no espelho de uma loja e ficar surpresa e quase assustada com a mudança ocorrida no meu rosto: sou morena e magra, mas tenho, ou melhor, tinha um rosto oval regular, isto é, sem visíveis desproporções entre a parte superior e a inferior. Pois bem, agora a parte inferior do meu rosto parecia delgada e magra. A boca parecia mais larga, o nariz mais longo. E os olhos, sem dúvida, haviam-me "comido" a cara. De grandes fizeram-se enormes, com uma expressão que nunca lembrava ter tido: cúpida, ávida, voraz.

Com aqueles olhos exorbitantes e fascinados, inspecionava minuciosamente a vitrine. Em seguida, entrava com decisão na loja e comprava. Não comprava um objeto só, digamos, uma minissaia, mas cinco, dez objetos todos iguais: cinco, dez minissaias. Procurava conferir-me uma atitude de compradora normal, ereta contra o balcão, as duas mãos sobre a bolsa, os olhares nas mercadorias que as vendedoras pouco a pouco me mostravam. Mas alguma coisa como um mecanismo irrompia repentinamente dentro de mim. Estendia a mão e dizia: "Compro isso, e isso, e isso. Mas desse eu levo quatro. E daquele outro, seis." A minha voz ao mesmo tempo imperiosa e insegura ressoava agressivamente entre a falação e o vai-e-vem das lojas; mais de uma vez, surpreendi as vendedoras trocando olhares de furtivo e irônico entendimento enquanto apressavam-se a me atender.

$\mathrm{Na}$ realidade, a compra, eu sabia bem, era o resultado de uma espécie de explosão da angústia há muito reprimida e repelida. Ouvi uma vez duas vendedoras, no momento em que eu entrava, falarem-se à meia-voz, com pressa: "Lá vem a louca". Erravam, como costuma acontecer nesses casos. Não apenas eu não era nem um pouco louca, como também fazia todas aquelas compras, aparentemente desreguladas e caóticas, para não me tornar louca de verdade, com a precisa e consciente intenção de aliviar minha quase insuportável tensão.

Devo dizer que, na indiscriminada voracidade do meu comprar asfixiante, podiase distinguir um critério de escolha: eu não comprava, olhando bem, qualquer coisa; comprava exclusivamente muitos exemplares de peças de roupa. A minha preferência era pela roupa mais pessoal, quer dizer, pelos trajes que estão sob as roupas e em contato com a pele: as meias, os sutiãs, as cintas-ligas, as calcinhas, as meias-calças, as luvas, as combinações. Eu tinha gavetas cheias, transbordantes de meias nunca usadas, fechadas em seus saquinhos de celofane; emaranhados de elásticos de todas as cores; 
montes de sutiãs de tecidos dos mais variados desenhos. Mas as calcinhas pretas, rosa, verdinhas, azul-claras, furadinhas, transparentes, opacas, reforçadas, decoradas com bordados, com laços, simples ou complicadas, de colegial ou de cortesã eram de longe o objeto mais colecionado. Imediatamente depois, vinham por importância as meias-calças, as meias, os sutiãs. Imaginem agora essas roupas suspensas no vazio, na ordem em que geralmente são vestidas e terão o invólucro vazio do corpo feminino, aliás, o mesmo corpo como aparece aos homens no momento breve e, para eles, inebriante, que se interpõe entre a já ocorrida conquista e o sexo iminente. Mas o que realmente significava para mim essas compras? Eu ainda não sabia. Sentia, no entanto, obscuramente que transformava em rito liberatório a situação contingente e casual que estava na origem da minha angústia.

Infelizmente havia um dia em que eu não podia fazer compras e, assim, liberarme da angústia: o domingo. E, de fato, em confirmação da virtude terapêutica do adquirir, o domingo era para mim um dia assombroso, o pior da semana. Ficava em casa sozinha, porque Siro que nos dias úteis me traía, dedicava os domingos à partida de futebol; e eu não sabia o que fazer. Não conseguia ficar parada, ia e vinha pelos cômodos e corredores e sacadas; enquanto isso, mordia os lábios, torcia as mãos, queria gritar, bater a cabeça contra as paredes, arrancar-me os cabelos, rolar pelo chão. De vez em quando, ia ao guarda-roupa, abria os armários, olhava para a roupa que as gavetas regurgitavam, como se quisesse, contemplando-lhes a misteriosa abundância, remontar à origem da relação, para mim ainda obscura, entre a infidelidade do meu marido e o meu frenesi consumista. Mas a roupa não me dava a resposta que eu procurava. Meu marido me traía: isto era um fato; e eu era uma louca que comprava dez sutiãs de uma vez: isto era outro fato. A relação entre os dois fatos ainda não se revelava.

Um domingo, Siro saiu como sempre para ir ao estádio e eu me senti verdadeiramente à beira da loucura. Depois, de repente, eu me disse que talvez vender far-me-ia o mesmo efeito benéfico de comprar. De onde me veio essa ideia, não sei; provavelmente, da reflexão que tanto para vender como para comprar são necessários objetos, isto é, coisas inanimadas das quais se dispõe como se quer por meio do dinheiro. Eu tinha, até então, comprado; por que não tentaria vender? Dependureime rapidamente ao telefone e digitei o número de uma dona de brechó quem há algum tempo oferecera-se para comprar qualquer vestido ou outra roupa de que eu já não precisasse mais. Encontrei-a em sua casa; e mostrou logo interesse ouvindo-me enumerar convulsivamente as numerosas peças do meu enxoval de neurótica. Mas senti o coração parar quando a mulher me disse que hoje, sendo domingo, não arredaria o pé de casa.

Assim não havia nada que fazer. Não podia comprar nada e não podia vender nada. Vesti, num turbilhão de desespero, o casaco e fui de carro ao centro da cidade 
como fazia nos outros dias. Estacionei o automóvel e comecei a caminhar ao longo das lojas de uma das ruas mais elegantes da cidade. As lojas estavam fechadas, mas as vitrines cheias de objetos expostos permitiam longas demoras contemplativas. Era o primeiro domingo, pouca gente passava, era outono, com o sol de outubro que é tão doce em Roma. Então, enquanto eu contemplava fascinada uma exposição de camisetes, senti tocarem-me o braço. Voltei-me e vi um homem nem feio nem bonito, nem jovem nem velho, de fato, um homem qualquer de meia idade, que me dava sinal, indicando o carro estacionado não muito longe. Mal o olhei, olhei o carro. Em seguida, com a mesma pressa com que costumava fazer minhas compras, aceitei com um balançar de cabeça, indo para o lado dele. Entramos no carro e partimos.

Não trocamos nem uma palavra até termos saído da cidade. Daí de repente ele disse: "Gosta das camisetes, hein. Hoje é domingo; mas amanhã com o dinheiro que vou lhe dar daqui a pouco vai poder comprar até mais de uma". Essa frase fez-me entender finalmente, como por uma iluminação repentina, a relação que ligava a infidelidade do meu marido à minha mania por compras. Enquanto o meu, digamos assim, "cliente" continuava a dirigir em silêncio, eu me disse que, no meu relacionamento com meu marido, desde o princípio, para ele, eu não fui mais do que um objeto que esperava ser "usado", ou se preferir, "consumido". No nosso caso, o uso, o consumo eram as carícias, os beijos, as relações, os orgasmos. Mas meu marido, depois de apenas dois meses de matrimônio, cessara quase que completamente de "usar-me", de "consumirme”, enfim, de ter prazer comigo. E então, depois de ter-me iludido em ser para ele a mulher que se ama, pela primeira vez, eu tinha descoberto que não passava de um objeto que se pode ou não se pode usar, um bem que se pode ou não se pode consumir e que de qualquer modo não possui uma existência autônoma fora do uso e do consumo.

Mas dos objetos cansa-se e, então, são repostos ou jogados fora. Assim tinha feito Siro comigo: não me usara mais; e eu estava insegura se agora devia considerarme o vaso quebrado que se joga no lixo ou então o vaso intacto que se repõe no armário, mas de cujo desenho cansou-se.

Naturalmente tudo acontecera fora da minha consciência, no meu inconsciente. Para liberar-me da angústia, inconscientemente, fingira comigo mesma de ser meu marido e começara a consumir roupas que, de certo modo, fosse pelo uso a que eram destinadas, fosse por suas formas, podiam simbolizar o meu corpo desprezado. Tornara-me, por fim, consumidora, pois tinha me sentido não consumida. Depois que, por exemplo, meu marido tinha parado, como lhe acontecia nos primeiros tempos do nosso amor, de jogar-me na cama, depois do almoço, de rasgar-me a calcinha e fazer amor comigo sem me despir; eu tinha comprado dezenas e dezenas de calcinhas. Mas 
agora, neste carro que corria pela Flamínia ${ }^{1}$ levando-me ao lugar onde, como uma mercadoria qualquer comprada em uma loja, seria consumida pelo meu desconhecido comprador, eu voltava a ser o objeto que fui nos primeiros tempos do matrimônio. Não me identificava mais com meu marido, transformando-me em compradora de roupas que simbolizavam o meu corpo. Eu oferecia, ao contrário, meu corpo em carne e osso diretamente à venda a um comprador real e de forma alguma simbólico. Todavia, como eu não buscava o prazer, não precisava de dinheiro e, provavelmente, ainda amava meu marido, contentava-me de fingir a venda, como em uma espécie de rito.

De súbito, reparei algo de inquietante e de ameaçador no meu companheiro, o qual, depois da frase sobre as camisetes, não tinha mais aberto a boca. Voltei-me um pouco e olhei-o para observá-lo melhor. Dirigia, dir-se-ia, com ferocidade, a cabeça esticada para frente, os olhos cúpidos fixos no asfalto, andando com o carro em alta velocidade, enfiando por ruas e bifurcações como se fossem as minhas pernas abertas. Então, sem se dirigir a mim, ele disse com uma espécie de concentrado furor: "Você é aquela que fez a brincadeira da doença comigo aquela vez. Não me reconhece? Mas dessa vez, com doença ou não, vai ter que fazer amor. Mesmo morta”.

\section{Referências Bibliográficas}

MORAVIA, Alberto. "Venduta e comprata”. Il paradiso. Milano: Bompiani, 1970. p. 21-31.

Submissão: $18 / 05 / 2020$

Aceite: $19 / 08 / 2020$

https://doi.org/10.5007/2176-8552.2019.e73769

Esta obra foi licenciada com uma Licença Creative Commons Atribuição-NãoComercial 4.0

1 Via Flamínia: Atualmente é uma estrada consular que liga Roma a Rimini. Feita nos anos 220 a 219 a.C. a mando de Gaio Flaminio Nepote. A Via Flamínia foi por muito tempo a primeira e, depois, a estrada mais importante a ligar Roma ao norte da Itália. 